\title{
NEMESNYÁR KLÓNOK FAANYAGTANI JELLEMZŐKHÖZ KÖTHETŐ GÉNJEINEK GENETIKAI VÁLTOZATOSSÁGA
}

\author{
Cseke Klára', Köbölkuti Zoltán Attila1', Benke Attila', Rumi Andrea', Báder Mátyás², \\ Borovics Attila ${ }^{1}$ és Németh Róbert ${ }^{2}$ \\ ${ }^{1}$ NAIK Erdészeti Tudományos Intézet \\ ${ }^{2}$ Soproni Egyetem, Simonyi Károly Müszaki, Faanyagtudományi és Müvészeti Kar
}

\begin{abstract}
Kivonat
A nemesnyárak kiemelkedő gazdasági jelentőséggel bírnak. A bemutatott vizsgálat legfőbb célja egy olyan kutatási metodika ismertetése, amely a faanyag tulajdonságaiért felelős kulcsenzimek kódoló régióinak azonosításából indul ki, bemutatva a genomikai alapokra helyezett nemesitési technológiákban rejlő lehetőségeket. A vizsgálatunk első szakaszában 24 különböző, a faanyagképződés szempontjából releváns enzim kódoló régiójára terveztünk primerpárokat. Összesen 55 saját fejlesztésű primerpárt teszteltünk, 47,27\%-os sikerességgel. Ezután nyolc enzimet választottunk ki részletesebb elemzésre hét nyárfaj és 11 hibrid klón bevonásával, összesen 23 nyár genotípus vizsgálata révén. A kiválasztott enzimek egy része a lignifikáció folyamatában vesz részt (COMT, CCOAOMT, SAMS), egy másik csoport a $\mathrm{K}^{+}$-függő xylogenezis során tölt be kulcsszerepet (Kt, ptk2, SKOR), míg a harmadik csoport (endo-1,4-b-xylanase, Araf-ase) a mikrofibrilla szög alakulásához köthetö. A sikeresen amplifikált és azonosított 13 markerrégió révén összesen 188 szekvenciát elemeztünk és 90 SNP-t azonosítottunk. Értékeltük a polimorf helyek számát, a nukleotid diverzitást, az inszerciók/deléciók számát, az SNP-k típusát, a rekombinációs események minimális számát, illetve azonosítottuk a konzervatív szakaszokat. Eredményeink bemutatása során részletesen tárgyaljuk a vizsgálatban rejlö alkalmazási lehetőségeket.
\end{abstract}

Kulcsszavak: SNP marker, nyár, faanyagtani jellemzők

\section{ALLELIC VARIATION IN CANDIDATE GENES ASSOCIATED WITH WOOD PROPERTIES OF CULTIVATED POPLARS}

\begin{abstract}
Poplars represent high economic value. The aim of the present study was to initiate a research methodology that at first identifies candidate genes encoding enzymes with wood property phenotypic traits, towards the aim of developing a genomics-based breeding technology. As a first step, primer pairs were designed on the coding region of 24 candidate genes. 55 primer pairs were tested with $47.27 \%$ success rate. In the next phase, eight enzymes were selected for further analysis on 23 genotypes containing seven different poplar species and 11 hybrids. One group of the analyzed enzymes is involved in the lignification process (COMT, CCoAOMT, SAMS), another group (Kt, ptk2, SKOR) holds a key function in $\mathrm{K}+$-dependent xylogenesis, while two more enzymes (endo-1,4-b-xylanase, Araf-ase) have a role in determining microfibril angle. 13 different marker regions were successfully amplified, and 188 sequences were analyzed, altogether resulting in 90 SNPs. The number of polymorphic sites, nucleotide diversity, the number of insertions/deletions, the minimum number of recombination events and the linkage disequilibrium were calculated, while the character of SNPs and conserved DNA regions were identified as well. Potential application fields are discussed along with the presented results.
\end{abstract}

Keywords: SNP markers, Populus, wood property 


\section{BEVEZETÉS}

A mintegy 35 holarktikus fajt és számos hibridet magába foglaló nyár nemzetség (Populus L.) morfológiailag és ökológiailag is erősen differenciált. A fajok jellemzően pionír jellegüek, és a mérsékelt égöv enyhébb éghajlatú régióiban, valamint a szubtrópusok arid vidékein tenyésznek (Gencsi \& Vancsura 1992). Közülük számos faj és hibrid bír kiemelt gazdasági jelentőséggel.

Amellett, hogy gyors növekedésük okán a termesztett nyárak energetikai célú felhasználásra is alkalmasak, faanyaguk széles körben hasznosítható, pl. rost-, papir- és gyufaipari alapanyagként, valamint forgácslapok, rétegelt lemezek, csomagoló rekeszek, raklapok és bútor- és épületszerkezeti elemek gyártására (Komán 2012). A nyár faanyag színe, keménysége és szilárdsága különböző modifikálási módszerekkel (gőzöléssel, hidrotermikus kezeléssel, olajban való főzéssel, tömörítéssel stb.) a felhasználási céloknak megfelelően módositható (Bak \& Németh 2012, Horváth et al 2012).

Gazdasági jelentőségükre való tekintettel a nemesnyárak szelekciója napjainkban is tartó folyamat. A megfelelő törzsalak, növekedés és károsítókkal, kórokozókkal szembeni tolerancia mellett kiemelt célként jelent meg olyan feldolgozás szempontjából fontos faanyagtani tulajdonságok javitása, mint a fatestsürüség vagy rostminőség (Christensen et al 2000). Hagyományos nemesitési módszerekkel e tulajdonságok módositása - kiváltképp a faanyagtani jellegeké - csak hosszú távon lehetséges, köszönhetően a nyárak több évtizedet is felölelő termesztési ciklusának. Erre a problémára nyúijthat megoldást a molekuláris genetika, amelyhez mindenekelőtt az egyes faanyagtani jellegek kialakulásáert felelős élettani mechanizmusok, és ezek genetikai szabályozásának megismerése szükséges.

A faanyagképződés egymást követő lépések sorozata, amely magába foglalja a sejtosztódást, sejtnövekedést, a sejffalvastagodást (a cellulóz, a hemicellulózok, a sejtfal fehérjék és a lignin bioszintézisével és beépülésével együtt), a programozott sejthalált és a gesztesedést (Barnett \& Bonham 2004). A növényi sejtfal vázeleme a cellulóz, amely egy $\beta$-D-glükózból származtatott poliszacharid. A hosszú cellulóz láncmolekulák kötegbe, elemi fibrillába rendeződnek, szabályos rozetta szerkezetü struktúrát alkotva. A cellulózláncok között oldalirányban kialakult másodlagos kötések szabályos szerkezeti szimmetriát mutatnak, és ez a kristályos szerkezet biztosítja a fibrillák nagyfokú kémiai stabilitását és kedvező szilárdsági tulajdonságait. Ezek az elemi szerkezeti egységek egymással párhuzamosan elhelyezkedve sürü szövedékben mikrofibrillát hoznak létre. A mikrofibrillák épitik fel a különböző sejtfalrétegeket. A mikrofibrillákon belül az elemi fibrillák között hézagok, rések találhatók (intermicelláris üregek), ahová a vízmolekulák és egyéb anyagok képesek beékelödni. A xilém sejteiben, növekedésük befejeztével megkezdődik az elsődleges sejtfal vastagodása, illetve a másodlagos sejffal kialakulása. A folyamat záró lépése a lignifikáció. A lignin bonyolult összetételü aromás vegyület, hálózatos, amorf szerkezettel. A hemicellulózok (xilán, arabán, mannán, galaktán) és a pektinek keresztkötések révén összekötő szerepet töltenek be a cellulóz rostok és a lignin között. A lignifikáció során a mikrofibrillák közti interfibrilláris üregeket nagyrészt lignin tölti ki, ezáltal megnövelve a faanyag nyomószilárdságát és sürủségét. Továbbá hemicellulózok, pektin, ásványi anyagok (hamualkotók), víz, valamint egyéb, kisebb méretü járulékos anyagok (fenolszármazékok, gyanták, terpének stb.) is lerakódhatnak. A cellulóz adja tehát a sejtfal alapvető vázát, míg a hidrofób lignin teszi azt megfelelően erőssé a külső terheléssel és ellenállóvá a víztranszport során fellépő nyomással szemben.

A másodlagos sejtfal S2 rétege a sejtfal legvastagabb egysége, ezáltal a legmeghatározóbb a faanyag tulajdonságait tekintve. Az S2 sejtfalréteget felépitő mikrofibrilláknak a sejt hossztengelyéhez viszonyított lefutási szöge a mikrofibrilla szög ('microfibril angle', MFA). A fák növekedése során a fiatal egyedek esetében a nagyobb MFA nagyobb rugalmasságot biztosit, ami például a széllel szembeni ellenállás szempontjából előnyös, míg a később képződő, idősebb sejtek esetében az alacsony MFA kellő szilárdságot ad a megnövekedett koronaméretből adódó tömeg megtartásához (Barnett \& Bonham 2004). A MFA értéke szoros összefüggést mutat a faanyag szilárdságával, zsugorodás-dagadásával, valamint rugalmassági jellemzőivel (Donaldson 
2008). A kisebb MFA kedvezőbb mechanikai jellemzőket biztosít. A faanyag keménységével is jól korreláló longitudinális rugalmassági modulusz ('longitudinal modulus of elasticity', MOE) alakulását a sürüség mellett mintegy 85\%-ban a MFA értéke határozza meg (Evans \& llic 2001).

A faszerkezetet meghatározó élettani folyamatok lebonyolitásában és szabályozásában specifikus fehérjék, enzimek és transzkripciós faktorok vesznek részt. A sejtfal létrejöttének és a fás növényekre jellemző másodlagos vastagodás sejtszintű folyamatainak feltárásában újabb és újabb eredmények születnek, áthelyezve ezzel a hangsúlyt a szöveti szintű megfigyelésekről az egyes sejtekben lejátszódó, sejtspecifikus folyamatokra (Lampugnani et al 2018, Meents et al 2018, Tobias et al 2020). A sejtfal mátrix kialakulásában és módosulásában a cellulóz szintáz enzimek (CESA) mellett, a xilémspecifikus glikoziltranszferáz enzim játszik kulcsfontosságú szerepet (Geisler-Lee et al 2006, McFarlane et al 2014). A fásszárúakban megtalálható vaszkuláris kambiumra és a vele szomszédos differenciálódási zónára a sejtfalmódosító enzimeket kódoló gének magas expressziója jellemző (Mellerowicz \& Sundberg 2008). A másodlagos sejtfalvastagodáshoz a sejtfal bioszintézis átprogramozása szükséges a sejtfalvastagodás indukálásáért felelős transzkripciós faktorok aktiválása által (Zhong \& Ye 2007). A sejtfal egyes rétegeiben változik a mikrofibrillák felépítése, ill. a cellulóz és a mátrixanyagok aránya (lignin, hemicellulózok, pektin). Expressziós vizsgálatok kimutatták, hogy cellulóz szintáz fehérjék fontos szerepet játszanak a másodlagos sejtfal és a xilém szöveteinek bioszintézisében (Mutwil et al 2008). A MFA nagyságát pedig jellemzően a mikrotubulusok (a sejtszervecskék rögzitéséért felelős citoszkeleton alapvető komponensei) befolyásolják, mely tényt alátámasztani látszik az a- és ß-tubulinok nagyarányú expressziója a xilém másodlagos sejtfalképződésekor (Oakley et al 2007).

A nyárak viszonylag kis méretü genommal rendelkeznek (550 Mb) (Bradshaw \& Stettler 1993). A rendelkezésre álló géntérképeket felhasználva már számos, a faanyagképződésben szerepet játszó gén működését vizsgálták (Li et al 2006), elősegítve a faanyagképződés folyamatának jobb megismerését. Ugyanakkor, a genom meghatározott pontján előforduló egy bázispárnyi eltérések (egypontos nukleotid-polimorfizmus, 'single-nucleotide polymorphism', SNP) nyárak faanyagtani tulajdonságaival kapcsolatos kutatásokban való alkalmazásra kevés példa akad. Részben emiatt, illetve köszönhetően annak, hogy az SNP-k potenciálisan a legjobb genetikai markereknek tekinthetők, nagy számuk, valamint adaptív jellegekkel való kapcsolatuk okán (González-Martínez et al 2006), kutatásunkhoz ezt a módszert választottuk. Jelen tanulmányban a korábban közölt eredményeink (Köbölkuti et al 2019) összefoglalásán túl, bemutatjuk a kutatási területen tett további lépéseinket és kitérünk a jövőbeni alkalmazási lehetőségekre is. Az ismertetni kívánt kutatási feladataink a következők: 1) faanyagképzéssel kapcsolatos funkcionális gének azonosítása nyilvánosan elérhető genom adatbázis szekvencia adatai alapján, 2) primerek tervezése ezekre a génszakaszokra, 3) polimorf szekvenciák azonosítása a hazai nyártermesztésben alkalmazott nyár fajták genomjában, végül 4) „klónspecifikus” haplotípusok azonosítása a célrégiókban, későbbi, fenotípus adatokkal történő összehasonlító genetikai vizsgálatok megalapozása céljából.

\section{ANYAG ÉS MÓDSZER}

\section{Markerfejlesztés}

A markerfejlesztés első lépéseként irodalmai adatok alapján egy olyan adatbázis kiépítését végeztük el, amelybe a faanyagképződés folyamatában nagy valószínűséggel szerepet játszó kulcsfehérjéket gyüjtöttük össze. A kiválasztott fehérjékhez az NCBI adatbázisból (http://www.ncbi.nlm.nih.gov, 2018.03.07) rendeltük hozzá annak kódoló szekvenciáját a következő kritériumoknak megfelelően: elsőként a Populus nemzetségen belül azonosított, génexpressziós vizsgálatok nyomán rögzített, ún. EST ('expressed sequence tag') szekvenciákat kerestünk. Amennyiben a nemzetségen belül ilyen találat nem állt rendelkezésre, a keresést az összes kétsziküre ('eudicots') kiterjesztettük. 
EST szekvenciákon történő PCR (polimeráz láncreakció, 'polymerase chain reaction') primerek tervezése során figyelembe kell vennünk a különböző hosszúságú, ismétlődő intronok esetleges jelenlétét a vizsgálni kívánt szekvenciában. Ezek az ismétlődő mintázatok nagymértékben befolyásolhatják a primerek bekötődését a PCR során, továbbá egyes esetekben túl hosszú amplifikálandó szekvenciát eredményeznek. Emiatt az EST BLAST adatbázisunk szekvenciáit az NCBI BLAST Genomes eszköztára (https://blast.ncbi.nlm.nih.gov/Blast. cgi) alkalmazásával teszteltük. Ebben a lépésben a Populus trichocarpa (taxid 3694) faj genomjában kerestünk az EST adatbázis szekvenciáival homológ szakaszokat a következő szűrőbeállitással: 1) a legalacsonyabb E-érték <0,001 legyen, (2) az azonosság ('identity') értéke minimum 98\%, és (3) HSP hosszúság 100 és 1000 bp közé essen. Ezen lépések után 55 szekvencia került kiválasztásra a primertervezéshez, amelyhez a Primer 3 Plus szoftvert (https://primer3plus.com/cgi-bin/dev/primer3plus.cgi) alkalmaztuk. Az így nyert primerpárok in silico tesztjét az NCBI Primer-BLAST eszköztár (https://www.ncbi.nlm.nih.gov/tools/primer-blast/ index.cgi) segítségével végeztük el, az esetleges paralóg lókuszokon történő, párhuzamos amplifikációk kiszűrése érdekében.

\section{Vizsgált növényanyag}

A vizsgálathoz összesen 23 nyár klónt választottunk ki, amelyek között szerepelnek ismert magyar nemesítésű Populus × euramericana [Dode] Guinier hibridek ('Pannónia', 'Koltay', 'Kopecky'), ígéretes magyar nemesítésü hibrid klónok ('Sv-656', 'Sv-761', 'Sv-874', 'Sv-890'), illetve nemzetközileg is ismert, Belgiumból, Olaszországból és Lengyelországból származó fajták ('Beaupre', Raspalje' [Populus × interamericana Brockh.], 'I-214' [Populus × euramericana], 'Kornik-21' [Populus maximowiczii A. Henry × Populus × berolinensis Dippel]). A mintasort kiegészítettük továbbá hét Populus fajhoz tartozó mintaegyeddel, amelyek a következők voltak: Populus nigra L. ('Lassicsárda 7', 'Lébény 211', Győr 203'), Populus deltoides Marsh. ('Durvakérgü', 'S-154', 'S 307-24', 'S 332-1'), Populus trichocarpa Torr. et Gray ('Muhle Larsen'), Populus grandidentata Michx. ('227'), Populus alba L. ('Villafranca'), Populus tremula L. ('105'), Populus × canescens Sm. ('65'). Ezek a genotípusok nagyrészt nemesítési alapanyagként használt szelektált törzsfák közül kerültek ki, illetve korábbi vizsgálatokból származó, egyéb hazai nyár fajok egyedei voltak. A vizsgálati növényanyag a NAIK ERTI ex situ géngyüjteményéből (Sárvár - Bajti) származott. A mintavétel során a DNS-extrakcióhoz növedékfúróval egy rövid furatot vettünk a törzsből. A mintasort kiegészítettük továbbá korábbi vizsgálatokból származó DNS mintákkal, amelyek esetében a kiindulási növényanyag levélszövet volt.

\section{Laboratóriumi munkafázis}

A DNS extrakcióhoz kb. egy $\mathrm{cm}^{2}$ friss levélszövetet, illetve növedékfúróval vett furatból $10 \mathrm{mg}$ faanyagot folyékony nitrogénnel steril mozsárban porrá őröltünk. Az extrakcióhoz az ATMAB protokollt (Dumolin et al 1995) alkalmaztuk. Az extrakció eredményességét, továbbá a kinyert DNS-oldatok koncentrációját 0,5\%-os agaróz gélelektroforézissel ellenőriztük.

A PCR elvégzéséhez szükséges, saját tervezésű oligonukleotid primerpárokat az IDT-nél (Integrated DNA Technologies, Bio-Science Kft.) szintetizáltattuk, standard kisózásos eljárással. Első lépésként 55 , újonnan tervezett primerpár PCR tesztelését végeztük el. Az alkalmazott PCR mastermix Isabel et al (2013) nyomán a következő összetételű volt $15 \mu$ l végtérfogatra elkészítve: $10 \mathrm{ng} / \mu$ lemplát DNS, $1 \times$ PCR puffer (Promega

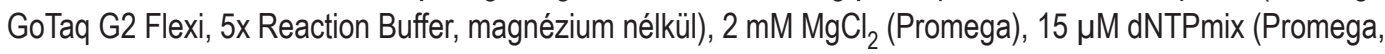
$10 \mathrm{mM}$ egyenként), 0,5 unit polimeráz enzim (Promega GoTaq G2 Flexi, $5 \mathrm{U} / \mu \mathrm{l}$ ) és 0,13 $\mu \mathrm{M}$ forward és reverse irányú primer. A PCR-hez Veriti Personal Thermocycler (Applied Biosystems) készüléket használtunk, a következő programon: elődenaturáció $95^{\circ} \mathrm{C} 3$ percig, majd $94^{\circ} \mathrm{C} 30$ másodpercig, primer bekötődés $\mathrm{T}_{\text {ann }}=50^{\circ} \mathrm{C} 45$ 
másodpercig, lánchosszabbítás $72^{\circ} \mathrm{C} 90$ másodpercig, a három lépés ismételve 35 cikluson keresztül, végül záró lánchosszítás $72{ }^{\circ} \mathrm{C} 10$ percig. A PCR sikerességének ellenőrzésére $2 \%$-os agaróz gélelektroforézist (Roti Agarose, Roth $\mathrm{GmbH}$ ) alkalmaztunk, 1 x TAE pufferben, $120 \mathrm{~V}$ feszültségen, egy órán át futtatva, GelRed (Biotium) festékkel. A PCR-t a további vizsgálatokhoz megfelelőnek tekintettük, amennyiben a gélképen a megfelelő mérettartományban egyetlen sáv volt látható. Többsávos mintázat esetében, az adott primerpárnál $\mathrm{T}_{\text {ann }}=55^{\circ} \mathrm{C}$ alkalmazásával megismételtük a PCR-t, a reakciókörülmények optimalizálása érdekében.

A tesztelés után az egy sávként megjelenő PCR termékek közül választottuk ki azokat, amelyeket lehetséges SNP polimorfizmus detektálása érdekében szekvenálással tovább elemeztünk. Az első ütemben a következő hat célgén, összesen hét szekvenciarészletét elemeztük a teljes mintasoron: COMT, CCOAOMT, K-transporter, ptk, SAMS, SKOR. A második ütemben részben tovább folytattuk két célgén (CCoAOMT, SAMS) vizsgálatát további négy szekvenciarészlet bevonásával, illetve két újabb fejlesztésü, a MFA alakulásához köthető markert, az endo-1,4b-xilanázt (a továbbiakban EC3218) és a-L-arabinofuranozidázt (a továbbiakban Araf-ase) vontunk vizsgálatba. A második ütem tesztelését négy mintán végeztük el ('l-214', 'Pannónia', 'Lébény 211', 'S-1-54'). A vizsgálatba vont nyolc enzim pontos megnevezését és föbb élettani funkcióját az 1. táblázat ismerteti.

A Sanger szekvenálásra kiválasztott PCR termékeket ExS-Pure enzimes PCR cleanup kit-tel (NimaGen BV, Nijmegen, The Netherlands) tisztítottuk a gyártó útmutatása alapján. A szekvenálást a BIOMI Kft. végezte (Gödöllö, Magyarország) ABI 3130xl készüléken. Az első ütemben, a 'Pannónia' klón esetében mindkét irányból (Fw, Rev) megtörtént a vizsgált hét régió szekvenálása. Következő lépésként mind a hét esetben kiválasztottuk a megfelelőbb BLAST találatot adó szekvenciavariánst a két irány közül, majd a további minták esetében már csak ebből az irányból szekvenáltunk. A második ütemben, a kiválasztott hat újabb primerpárral kapott amplikont, a vizsgált négy minta esetében mindkét irányból szekvenáltuk.

\section{Szekvenciaelemzés}

A nyers kromatogramok elemzését, illetve a szekvenciák szerkesztését első lépésben a BioEdit Sequence Alignment Editor 7.0.9.0 verziójú (Hall 1999) szoftverrel végeztük. A nem egyértelmü, átfedésben lévő dupla szekvenciák esetében a CodonCode Aligner 8.0.2 (CodonCode Corporation) Trace Recalling metódusát (Tenney et al 2007) alkalmaztuk a további elemzéshez. A nyers szekvenciák szerkesztése után a CLC Genomic Workbench 12.0-Viewing Mode (QIAGEN Bioinformatics) segítségével markerenként elkészítettük a vizsgált minták szekvenciáinak illesztését ('alignment') a következő beállitásokkal: gap open cost value 10, gap extension cost value 1, end gap cost 'as any other', very accurate (slow) mode. Az illesztett szekvenciákban azonosítottuk a potenciális SNP-ket és amennyiben szükséges volt, jelenlétüket újra ellenőriztük a nyers kromatogramon is a BioEdit segítségével. Ezután rögzítettük a vizsgált nyár klónokat elkülönítő SNPket, majd a lókuszokat az NCBI Genome Data Viewer (https://www.ncbi.nlm.nih.gov/genome/gdv/) eszköztár segítségével a következő diverzitási mutatók alapján értékeltük: polimorf lókuszok száma, nukleotid diverzitás, inszerciók/deléciók száma, SNP típusa (szinonim vagy nem-szinonim), rekombinációs események minimum száma, végül azonosítottuk a lókuszok konzervált régióit.

\section{EREDMÉNYEK}

A vizsgálatunk első szakaszában 55 saját fejlesztésű primerpárt teszteltünk, amelyeket 24 különböző, a faanyagképződés szempontjából releváns enzim kódoló régiójára terveztünk. A tervezett primerek közül 49 eredményezett PCR terméket és ezek közül 26 amplikon jelent meg egyetlen sávként az elektroforézis 
gélekben. A Populus trichocarpa genomban tervezett primerek 47,27\%-a volt ennek alapján sikeres. A 26 génszakaszból ezután hét került kiválasztásra a teljes, 23 mintából álló mintasoron történő szekvenciaelemzésre. A Kt 1, ptk 2/2 és SAMS 1 forward (Fw), a COMT 3, COMT 4, CCOAOMT 4, SKOR 3 fragmentumokat reverz (Rev) irányból szekvenáltuk az előzetes tesztelés eredményei alapján. A szekvenálás mind a hét génfragmens esetében elemezhető minőségű kromatogramot eredményezett a minták többségénél.

A CCoAOMT 4 marker esetén 13 minta ('Pannónia', 'Kopecky', 'Koltay', 'Durvakérgü', 'Sv-656', 'Sv-874', 'Sv-890', 'I-214', 'Raspalje', 'Beaupré', '227', '65', '105') kromatogramján bizonyos szekvenciarégió dupla görbeként jelent meg. Az adott mintáknál a génszakasz kettős átiratát külön-külön elemeztük, a feltételezett „eredeti” és „alternatív” (átfedő) szekvenciákat is figyelembe véve. A vizsgált mintaszám ebben az esetben 34-re emelkedett.

Munkánk második szakaszában az első fázisban is vizsgált SKOR, SAMS és CCoAOMT enzimeket kódoló gének újabb részeit, valamint a MFA-t meghatározó Araf-ase és EC3218 kódoló szekvenciáját sikerült felszaporítanunk, mindkét irányból szekvenálnunk, majd elemeznünk. Az előbbi esetében csupán két minta kromatogramja volt értékelhető. A CCOAOMT 1 marker három mintánál ('I-214', 'Pannónia', 'S-1-54') ugyancsak dupla lefutást mutatott a kromatogramok bizonyos szekvenciahosszán.

Összességében nyolc különböző gén fragmenseit amplifikáltuk és azonosítottuk 13 markerrégió segítségével. A nyolcból hét génszakaszt összesen 22 különböző nyár genotípuson vizsgáltunk, és összesen 188 szekvenciát elemeztünk. Eredményeinket a 2. táblázat foglalja össze. A vizsgált 78748 bázispárból 90 esetben találtunk egypontos nukleotid polimorfizmust. A mutációk száma szekvenciánként 0 (CCoAOMT 5) és 17 (CCoAOMT 4) között változott. A nukleotid diverzitás értékei 0,0000 (CCoAOMT 5) és 0,01109 (Kt 1) között voltak, 0,01575 átlaggal. Indel a 186 szekvencia közül 39-ben fordult elö, értéke a CCoAOMT 4 és a COMT 3 esetében volt a legmagasabb (15 és 14). Szinonim mutációt 25 amplikon esetében találtunk, értékük markerenként 1-től 9-ig terjedt. A legmagasabb érték a COMT 3 esetében (9) mutatkozott, két marker esetében szinonim SNP nem fordult elő. Konzervált régiót nyolc marker nem tartalmazott. A nem-szinonim egy bázisú mutációk száma (49) 0-10 között változott, a COMT 4 esetében mutatva a legnagyobb értéket. A nem-szinonim SNP-k egyike sem hozott létre korai stop kodont. Rekombinációs esemény a 13 vizsgált markerrégióban összesen 22 esetben fordult elő; a SKOR 3 különösen figyelemre méltó e tekintetben.

1. táblázat: A vizsgálatba vont nyolc enzim pontos megnevezése, az alkalmazott rövidítések és a föbb élettani folyamatban betöltött szerepük

Table 1: Name, abbreviation and main physiological function of the analysed eight enzymes

\begin{tabular}{|c|c|c|c|}
\hline Rövidítés & Enzim & Élettani szerep & Referencia \\
\hline COMT & caffeate O-methyltransferase (EC 2.1.1.68) & lignifikáció & Halpin 2004 \\
\hline CCOAOMT & Caffeoyl-CoA O-methyltransferase (EC 2.1.1.104) & lignifikáció & Takabe et al 2001 \\
\hline SAMS & S-adenosyl-L-methionine synthase (EC 2.5.1.6) & lignifikáció & $\begin{array}{c}\text { Vander Mijnsbrugge et } \\
\text { al } 2000\end{array}$ \\
\hline $\mathrm{Kt}$ & $\mathrm{K}$ transporter 1 (AKT1) / $\mathrm{K}^{+}$transzporter & $\mathrm{K}^{+}$-függő xylogenezis & $\begin{array}{c}\text { Langer et al 2002; } \\
\text { Fromm } 2010\end{array}$ \\
\hline ptk 2 & potassium channel 2 / $\mathrm{K}^{+}$csatorna & $\mathrm{K}^{+}$-függő xylogenezis & $\begin{array}{c}\text { Langer et al 2002; } \\
\text { Fromm } 2010\end{array}$ \\
\hline SKOR & potassium channel (SKOR) / K+ csatorna (,Shaker family') & $\mathrm{K}^{+}$-függő xylogenezis & $\begin{array}{l}\text { Arend et al 2005; } \\
\text { Fromm } 2010\end{array}$ \\
\hline EC3218 & endo-1,4-b-xylanase (EC:3.2.1.8) & $\begin{array}{c}\text { mikrofibrilla szög } \\
\text { alakulása }\end{array}$ & Tobias et al 2020 \\
\hline Araf-ase & beta-xylosidase/alpha-L-arabinofuranosidase 1 & $\begin{array}{c}\text { mikrofibrilla szög } \\
\text { alakulása }\end{array}$ & Tobias et al 2020 \\
\hline
\end{tabular}


2. táblázat: A DnaSP szekvencianalízis eredményei a 13 elemzett génszakaszon

Table 2: The results of the sequence analysis of the selected 13 gene sequences applying DnaSP

\begin{tabular}{|c|c|c|c|c|c|c|c|c|c|c|}
\hline 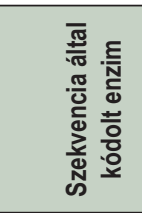 & 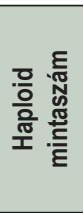 & 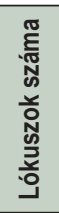 & 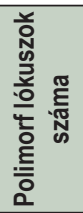 & 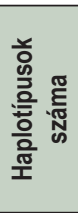 & 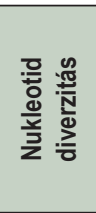 & 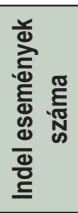 & 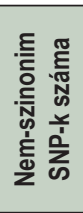 & 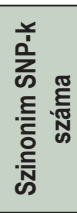 & 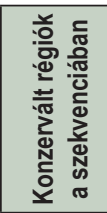 & 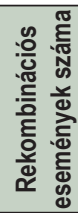 \\
\hline СОMT 3 & 21 & 149 & 9 & 7 & 0,01531 & 14 & 0 & 9 & - & 1 \\
\hline COMT 4 & 22 & 114 & 12 & 13 & 0,04176 & 1 & 10 & 3 & - & 3 \\
\hline Kt 1 & 22 & 164 & 7 & 8 & 0,01109 & 0 & 4 & 2 & $\begin{array}{l}53-127 \\
\text { lókuszok } \\
\text { közötti } \\
\text { régió }\end{array}$ & 1 \\
\hline CCOAOMT 4 & 34 & 166 & 17 & 10 & 0,01414 & 15 & - & - & $\begin{array}{l}1-87 \\
\text { lókuszok } \\
\text { közötti } \\
\text { régió }\end{array}$ & 1 \\
\hline ptk 2/2 & 21 & 140 & 8 & 8 & 0,01439 & 1 & 4 & 4 & - & 1 \\
\hline SAMS 1 & 22 & 180 & 8 & 9 & 0,01502 & 0 & 7 & 1 & - & 4 \\
\hline SKOR 3 & 21 & 78 & 7 & 10 & 0,01831 & 0 & 7 & 0 & - & 10 \\
\hline EC3218 & 4 & 597 & 6 & 4 & 0,00532 & 1 & 4 & 2 & \begin{tabular}{|l}
$350-597$ \\
lókuszok \\
közötti \\
régió
\end{tabular} & 0 \\
\hline Araf-ase & 2 & 503 & 1 & 2 & 0,00201 & 1 & 0 & 1 & - & 0 \\
\hline CCOAOMT 5 & 4 & 125 & 0 & 1 & 0,00000 & 1 & 0 & 0 & v & 0 \\
\hline CCOAOMT 1 & 7 & 183 & 6 & 4 & 0,01291 & 4 & 6 & 1 & \begin{tabular}{|l|}
$1-64$ \\
lókuszok \\
közötti \\
régió \\
\end{tabular} & 0 \\
\hline CCOAOMT 3 & 4 & 198 & 6 & 7 & 0,00992 & 0 & 5 & 1 & - & 1 \\
\hline SAMS 2 & 4 & 214 & 3 & 4 & 0,00637 & 1 & 2 & 1 & $\begin{array}{l}62-214 \\
\text { lókuszok } \\
\text { közöti } \\
\text { régió }\end{array}$ & 0 \\
\hline
\end{tabular}

\section{DISZKUSSZIÓ}

A genetikai markerek különböző egyedek ugyanazon DNS-szekvenciáiban fellépő eltérések detektálásán alapulnak. A már hozzáférhető genom adatbázisok alapján bioinformatikai tervezéssel akár meghatározott enzimefehérjék génjeire is rákereshetünk és különböző genotípusok génszekvenciáit hasonlíthatjuk össze ('candidate gene study'). Kétségtelen, hogy napjainkban már lehetséges akár teljes genomok vagy transzkriptomok elemzése, akár összehasonlitása a nagy áteresztőképességű újgenerációs szekvenálási technológiák (NGS) révén. Ezek az eljárások azonban továbbra is jelentős költségigényüek, különösen nagy mintaszám esetén. Az említett hátrányra való tekintettel, egy nagyobb volumenü munka első lépéseként, olyan új SNP markerek fejlesztését kezdtük el, amelyek egy későbbi - a genotípust a faanyag- és rostszerkezettel összevető - asszociációs vizsgálat alapját képezhetik, a hazánkban gazdaságilag jelentős, már regisztrált vagy ígéretes nyár klónok esetében. 
Kiindulásként, a faanyag fizikai tulajdonságainak kialakításában meghatározó szerepet betöltő, cellulóz és lignin bioszintézis enzimeit, valamint a MFA alakulásában szerepet játszó fehérjéket és ezek kódoló génjeit térképeztük fel. Az említett enzimeket szakirodalmi adatok alapján választottuk ki, a sejtosztódásra, sejtek expanziójára, sejtfalvastagodásra, a cellulózra, hemicellulózokra, sejtfal fehérjékre, valamint lignin bioszintézisre és lerakódásra, programozott sejthalálra és a geszt képződésére kifejtett hatásuk alapján. Az enzimek kétszikűekből származó kódoló génszekvenciáit az NCBI adatbázisból töltöttük le és homológiaalapú szekvenciakeresés révén a Populus trichocarpa genomi régióiban azonosítottuk. Az azonosított régiókra primereket terveztünk és a Populus nemzetség különböző fajain/hibridjein PCR során a kiválasztott régiót enzimatikusan felszaporítottuk. Eredményeink arra engednek következtetni, hogy bizonyos fajon, bizonyos genomi régiókra fejlesztett markerek számos egyéb Populus faj és hibrid esetében is jól alkalmazhatóak. A polimorfizmust mutató génlókuszok meghatározása révén a törzs-, illetve faanyagminőség szempontjából releváns gének variabilitásába nyertünk betekintést különböző nyárhibridekben. A nukleotid diverzitás feltárása így különféle funkcionális jellemzőkkel bíró gének szelekcióját is lehetővé teszi (Wright \& Andolfatto 2008), illetve a fatestképződés/nyugalmi állapot genetikai szabályozásának jobb megértését is segíti (Brunner et al 2004).

Az általunk vizsgált 188 szekvencia számos esetben tartalmazott indelt (bázisok beékelődését vagy kiesését) a szekvenciamotívumban a különböző genotípusok között. Az indelek hibrid nyárfajták esetében megfigyelt magas száma összefüggésben állhat e genotípusok fenotípusos előnyét meghatározó hibrid vigorral. A szakirodalom szerint ugyanis a hibrid teljesítmény (hibrid fölény vagy vigor) mögött megváltozott géndózis-kapcsolatok állnak. A poliploidok fajok közötti kereszteződések révén jönnek létre (Bradshaw \& Stettler 1993), tolerálva az inszerciót/deléciót az eltérő kromoszómakészleteknek köszönhető, egyfajta pufferhatás miatt (Henry et al 2015). Az indel események megjelenése az új fenotípusok kialakulásának fontos genetikai tényezője, azonositásuk jelentős szereppel bír a nemesítés során.

A vizsgálatban kimutatott nem-szinonim SNP-k közül néhány azért lehet különösen fontos, mivel ezek az általuk kódolt fehérje szerkezetét és müködését nagymértékben megváltoztathatják, ami eltérő fenotípus kialakulását eredményezheti. A CCOAOMT 4-ben található nem szinonim SNP-k a lignin összetételében és a másodlagos xilém kialakulásában eredményezhetnek változásokat, a káliumcsatorna SKOR kódoló szekvenciájának nem-szinonim SNP-i megváltoztathatják a faanyag kialakulásának $\mathrm{K}^{+}$-függő szabályozását, az endo-1,4-b-xilanáz konformációs változásai a MFA és ezáltal egyes fizikai-mechanikai jellemzők eltéréseit eredményezhetik.

Végül, a rekombinációs események feltárása, a fenotípusos változatosságot alapvetően meghatározó genomi régiók kapcsolt vagy éppen független öröklödési módjának azonosításához nyújt segítséget (Olson et al 2010). A jövőbeni genotípus-fenotípus asszociációs vizsgálatok optimális megtervezéséhez a kapcsoltsági viszonyok előzetes felmérése szükséges, amelyhez vizsgálataink jó alapot biztosítanak. Az itt közölt eredmények lehetőséget adnak például egy olyan komplex elemzés jövőbeni elvégzéséhez, amely különböző nyár klónok faanyagát alkotó lignin minőségi és mennyiségi összetételét veti össze, a folyamat genetikai szabályozásában feltárt változatossággal. A mérhető tulajdonságokkal korrelációt mutató genetikai mintázat ezután már a gyakorlati nyárnemesítésben is felhasználhatóvá válna, mint marker asszisztált szelekciós eszköz ('marker assisted selection', MAS). Hasonló módon hasznosítható a MFA-t befolyásoló genetikai háttérmechanizmusok elemzése, a folyamatban specifikusan résztvevő enzimek kódoló régióiban feltárt genetikai mintázat és a különböző nyár klónok esetében detektálható eltérések együttes értékelése révén. Végül pedig, a xylem képződésének folyamatában kulcsfontosságú szerepet játszó $\mathrm{K}^{+}$-függő mechanizmusokkal kapcsolatos vizsgálati eredményeink a kambiális aktivitás változásának, illetve hormonális (auxin függő) regulációjának feltárásához is értékes adalékokkal szolgálhatnak (Ache et al 2010). 


\section{ÖSSZEFOGLALÁS}

Az egyes nemesnyár fajták különböző tényezők (termőhely, kor, genotípus) által befolyásolt faanyagtani tulajdonságainak részletes értékelése kiemelkedő jelentőségü, hiszen az általuk nyert ismeretek alapvetően megszabják az egyes fajták termesztése során alkalmazandó termesztéstechnológiát, valamint faanyaguk ipari felhasználási lehetőségeit. Az alacsony sürüség például jobb hámozhatóságot, az alacsony lignintartalom kedvezőbb papíripari felhasználhatóságot jelenthet. A nemesnyárak esetében a felhasználási terület fajtánként változhat, és a jövőben újabb alkalmazási módok kerülhetnek előtérbe. Tekintettel arra, hogy a nagyobb fatestsürüségü fafajok iránti piaci igény folyamatosan növekszik, azok elérhető mennyisége azonban jellemzően nem változik, a helyettesítésükre alkalmas alapanyagok iránti igény fellendülése várható. $A$ tömörített nyár faanyag a jövőben akár parketta alapanyagként, vagy bútorgyártásra is alkalmazható lesz, kiegészítve vagy helyettesitve így a nagyobb fatestsürüségü fafajok faanyagát a piacon (Rademacher et al 2017).

Az itt bemutatott markerek új típusú elemző eszközként szolgálhatnak a nemesített nyárak faanyagtani jellemzőit meghatározó környezeti/genetikai hatások közül a genetikai komponens mélyebb feltárásához. A hagyományos nyárnemesítés hatékonyságát a marker által támogatott szelekció jelentősen növelheti (Neale \& Kremer 2011). Az irányított keresztezés tervezésekor olyan szülői klónok kerülnek kiválasztásra, amelyek a mérvadó faanyagtani tulajdonságaik tekintetében az átlagosnál jobb paraméterekkel rendelkeznek. Ugyanakkor a létrehozott utódnemzedék tesztelése, szelekciója kritikusan fontos lépés, mivel egy adott utódnemzedéken belül is jelentős különbségek lehetnek egyes genotípusok között az ipari felhasználhatóságot meghatározó kémiai és fizikai sajátosságokat illetően (Davison et al 2006). Az, akár magonckorban elvégzett, genetikai mintázat alapján történő szelekció révén jelentősen rövidíthető a vizsgálati ciklusidő, és egyúttal csökkenthető a csemetekerti, félüzemi és üzemi kísérletek költségráfordításának mértéke is.

A faanyagképződés és xylogenezis biokémiai folyamatainak egyre nagyobb mélységű feltárásával egyidőben, a kutatások egyre inkább interdiszciplinárissá válnak, összekapcsolva olyan tudományterületeket, mint a biokémia, anatómia, élettan és genetika, az alkalmazott kutatások meghatározó területeivel (Mizrachi et al 2017). A lignin szerepe újraértékelődik a biopolimer-gyártás rohamos fejlődésével (Glasser 2019, Tribot et al 2019), a mikroanatómiai struktúrák sejtszintű feltárása pedig elősegíti a modifikációs eljárások hatásmechanizmusának még pontosabb feltérképezését és ezáltal a különböző módszerek továbbfejlesztését (Song et al 2018, Báder et al 2019). A faanyag legtöbb mechanikai tulajdonságát nagymértékben meghatározó MFA klónonkénti változatosságának felmérésére pedig a gyors növekedésű, jellemzően rövid vágásfordulójú ültetvényekben alkalmazott fajtakör esetében érdemes külön figyelmet fordítani (Barnett \& Bonham 2004). A MFA értékében változás áll be a faanyagnak juvenilis fából érett fává történő fejlődése során, amely kisebb lefutási szöget és jobb mechanikai paramétereket eredményez. A gyors növekedésü ültetvényekből kikerülő faanyag esetében a juvenilis fa aránya nagyobb, így ennek a tényezőnek a faanyag minőségére gyakorolt hatását célszerű szem előtt tartani. A nemesnyárak ültetvényszerű termesztéstechnológiájának egy másik fontos alappillére az optimális termőhely kiválasztása, illetve a termesztés szempontjából még elfogadható, határ termőhelyek felmérése. A faanyagképződés $\mathrm{K}^{+}$-függő folyamatainak feltárása, illetve a klonális eltérések kimutatása segítséget nyújthat ezen szélsőséges termőhelyek esetében a megfelelő biztonsággal termeszthető fajta vagy akár fajtakör meghatározásában, illetve célzott szelektálásában.

\section{KÖSZÖNETNYILVÁNÍTÁS}

A furatminták gyüjtésében Takács Roland csemetekertvezető kollégánk (NAIK ERTI) volt a segítségünkre. A PCR termékek szekvenálását a gödöllői székhelyű Biomi Kft. végezte. A publikáció elkészítését az EFOP3.6.2-16-2017-00018 („,Termeljünk együtt a természettel - az agrárerdészet mint új kitörési lehetőség”) projekt támogatta a Széchenyi2020 program keretében. A projekt megvalósítását az Európai Unió támogatja, az Európai Szociális Alap társfinanszírozásával. 


\section{FELHASZNÁLT IRODALOM}

Ache P., Fromm J. \& Hedrich R. 2010: Potassium-dependent wood formation in poplar: Seasonal aspects and environmental limitations. Plant Biology 12(2): 259-267. doi: 10.1111/j.1438-8677.2009.00282.x.

Tribot A., Amer G., Alio M. A., de Baynast H., Delattre C., Pons A., Mathias J.-D., Callois J.-M., Vial C., Michaud P. \& Dussap C.-G. 2019: Wood-lignin: Supply, extraction processes and use as bio-based material. European Polymer Journal 112: 228-240. https://doi.org/10.1016/j.eurpolymj.2019.01.007.

Arend M., Stinzing A., Wind C., Langer K., Latz A., Ache P. \& Hedrich R. 2005: Polar-localised poplar K+channel capable of controlling electrical properties of wood-forming cells. Planta 223(1): 140-148. doi: 10.1007/s00425-005-0122-y.

Báder M., Németh R. \& Konnerth J. 2019: Micromechanical properties of longitudinally compressed wood. European Journal of Wood and Wood Products 77: 341-351.https://doi.org/10.1007/s00107-019-01392-0

Bak M. \& Németh R. 2012: Changes in swelling properties and moisture uptake rate of oil-heat-treated poplar (Populus $x$ euramericana cv. Pannonia) wood. BioResources 7(4): 5128-5137.

Barnett J.R. \& Bonham V.A. 2004: Cellulose microfibril angle in the cell wall of wood fibres. Biological Reviews 79: 461-472.

Bradshaw H. D. \& Stettler R. E. 1993: Molecular genetics of growth and development in Populus. In. Triploidy in hybrid poplars. Theoretical and Applied Genetics 86: 301-302.

Brunner A. M., Busov V. B. \& Strauss S. H. 2004: Poplar genome sequence : functional genomics in an ecologically dominant plant species. Trends in Plant Science 9(1): 49-56. doi: 10.1016/j.tplants.2003.11.006.

Christensen J. H., Baucher M., O'Connell A., Van Montagu M. \& Boerjan W. 2000: Control of lignin biosynthesis. Molecular biology of woody plants. Dordrecht, Springer: 227-228.

Davison B. H., Drescher S. R., Tuskan G. A., Davis M. F. \& Nghiem N. P. 2006: Variation of S/G Ratio and Lignin Content in a Populus Family Influences the Release of Xylose by Dilute Acid Hydrolysis. Applied Biochemistry and Biotechnology 129-132: 427-435.

Donaldson L. 2008: Microfibril angle: Measurement, variation and relationships-A review. International Association of Wood Anatomists Journal 29: 345-386.

Dumolin S., Demesure B. \& Petit R. J. 1995: Inheritance of chloroplast and mitochondrial genomes in pedunculate oak investigated with an efficient PCR method. Theoretical and Applied Genetics 91(8): 1253-1256. doi: 10.1007/ BF00220937.

Evans R. \& Ilic J. 2001: Rapid prediction of wood stinness from microfibril angle and density. Forest Products Journal 51: 53-57.

Fromm J. 2010: Wood formation of trees in relation to potassium and calcium nutrition. Tree Physiology 30(9): 1140-1147. doi: 10.1093/treephys/tpq024.

Geisler-Lee J., Geisler M., Coutinho P. M., Segerman B., Nishikubo N., Takahashi J. \& Sundberg B. 2006: Poplar carbohydrate-active enzymes. Gene identification and expression analyses. Plant Physiology 140(3): 946-962. doi: 10.1104/pp.105.072652.

Gencsi L. \& Vancsura R. 1992: Dendrológia - Erdészeti Növénytan II. Mezőgazda Kiadó, Budapest: 29, 330.

Glasser W.G. 2019: About Making Lignin Great Again - Some Lessons From the Past. Frontiers in Chemistry 7: 565. doi: 10.3389/fchem.2019.00565

González-Martínez S. C., Krutovsky K. V. \& Neale D. B. 2006: Forest-tree population genomics and adaptive evolution. New Phytologist 170: 227-238.

Hall T. A. 1999: BioEdit: a user-friendly biological sequence alignment editor and analysis program for Windows 95/98/NT. Nucleic Acids Symposium Series 41 (41): 95-98. doi: citeulike-article-id:691774.

Halpin C. 2004: Re-designing lignin for industry and agriculture. Biotechnology and Genetic Engineering 21(1): 229-248. doi: 10.1080/02648725.2004.10648057.

Henry I. M., Zinkgraf M. S., Groover A. T. \& Comai L. 2015: A system for dosage-based functional genomics in poplar. The Plant Cell 27(9): 2370-2383. doi: 10.1105/tpc.15.00349. 
Horváth N., Bak M. \& Németh R. 2012: Modification of poplar wood by different heat treatments. Poster presentation, 7. Thermowood Workshop, Drezda, 2012.04.26-27.

Isabel N., Lamothe M. \& Thompson S. L. 2013: A second-generation diagnostic single nucleotide polymorphism (SNP)based assay, optimized to distinguish among eight poplar (Populus L.) species and their early hybrids. Tree Genetics and Genomes 9(2): 621-626. doi: 10.1007/s11295-012-0569-5.

Komán Sz. 2012: Nemesnyár-fajták korszerű ipari és energetikai hasznosítását befolyásoló faanatómiai és fizikai jellemzők. Doktori értekezés, Nyugat-Magyarországi Egyetem, Sopron, 85 p.

Köbölkuti Z., Cseke K., Benke A., Báder M., Borovics A. \& Németh R. 2019: Allelic variation in candidate genes associated with wood properties of cultivated poplars (Populus), Biologia Futura 70(4): 286-294.

Lampugnani E.R., Khan G.A., Somssich M. \& Persson S. 2018: Building a plant cell wall at a glance. Journal of Cell Science 131(2), jcs207373. https://doi.org/10.1242/jcs.207373

Langer K., Ache P., Geiger D. et al. 2002: Poplar potassium transporters capable of controlling K+ homeostasis and K+-dependent xylogenesis. The Plant Journal 32(6): 997-1009. doi:10.1046/j.1365-313x.2002.01487.x

Li L., Lu S. \& Chiang V. 2006: A genomic and molecular view of wood formation. Critical Reviews in Plant Sciences 25(3): 215-233. doi: 10.1080/07352680600611519.

McFarlane H.E., Doring A. \& Persson S. 2014: The cell biology of cellulose synthesis. The Annual Review of Plant Biology 65: 69-94.

Meents M.J., Watanabe Y. \& Samuels A.L. 2018: The cell biology of secondary cell wall biosynthesis. Annals of Botany 121: $1107-1125$.

Mellerowicz E. J. \& Sundberg B. 2008: Wood cell walls: biosynthesis, developmental dynamics and their implications for wood properties. Current Opinion in Plant Biology 11(3): 293-300. doi: 10.1016/j.pbi.2008.03.003.

Mizrachi E., Verbeke L., Christie N. et al. 2017: Network-based integration of systems genetics data reveals pathways associated with lignocellulosic biomass accumulation and processing. Proceedings of the National Academy of Sciences 114. 201620119. 10.1073/pnas.1620119114.

Mutwil M., Debolt S. \& Persson S. 2008: Cellulose synthesis: a complex. Current Opinion in Plant Biology 11(3): 252-257. doi: 10.1016/j.pbi.2008.03.007.

Neale D. B. \& Kremer A. 2011: Forest tree genomics: growing resources and applications. Nature Reviews Genetics 12: 111-122.

Oakley R. V., Wang Y. S., Ramakrishna W., Harding S. A. \& Tsai C. J. 2007: Differential expansion and expression of alfa and beta-tubulin gene families in Populus. Plant Physiology 145(3): 961-973. doi: 10.1104/pp.107.107086.

Olson M. S., Robertson A. L., Takebayashi N., Silim S., Schroeder W. R. \& Tiffin P. 2010: Nucleotide diversity and linkage disequilibrium in balsam poplar (Populus balsamifera). New Phytologist 186: 526-536.

Plomion C., Leprovost G. \& Stokes A. 2001: Wood formation in trees. Plant Physiology 127(12): 1513-1523. doi: 10.1104/ pp.010816.1.

Rademacher P., Báder M., Németh R., Rousek R., Paril P., Baar J., Hornicek S., Dejmal A., Domeny J., Kudela J., Kutnar A., Neyses B. \& Sandberg D. 2017: European co-operation in wood research - from native wood to engineered materials. Part 2: densification modification in product development. In: Gurau L., Campean M., Ispas M. (eds): Proceedings of the International Conference Wood Science and Engineering in the Third Millenium (ICWSE 2017). Transilvania University, Brasov, Romania, 02-04.11.2017.: 469-478. (ISSN 1843-2689).

Song J., Chen C., Zhu S. et al. 2018: Processing bulk natural wood into a high-performance structural material. Nature 554: 224-228. https://doi.org/10.1038/nature25476

Takab, K., Takeuchi M., Sato T., Ito M. \& Fujita M. 2001: Immunocytochemical localization of enzymes involved in lignification of the cell wall. The Journal of Plant Research 114: 509-515. doi: 10.1007/PL00014018.

Tenney A. E., Wu J. Q., Langton L., Klueh P., Quatrano R. \& Brent M. R. 2007: A tale of two templates : Automatically resolving double traces has many applications, including efficient PCR-based elucidation of alternative splices. Genome Research 17(2): 212-218. doi: 10.1101/gr.5661407.5. 
Vander Mijnsbrugge K., Meyermans H., Van Montagu M., Bauw G. \& Boerjan W. 2000: Wood formation in poplar: identification, characterization, and seasonal variation of xylem proteins. Planta 210(4): 589-598. doi: $10.1007 /$ s004250050048.

Wright S. I. \& Andolfatto P. 2008: The impact of natural selection on the genome: emerging patterns in Drosophila and Arabidopsis. The Annual Review of Ecology, Evolution, and Systematics 39: 193-213. doi: 10.1146/annurev. ecolsys.39.110707.173342.

Zhong R. \& Ye Z. H. 2007: Regulation of cell wall biosynthesis. Current Opinion in Plant Biology 10(6): 564-572. doi: 10.1016/j.pbi.2007.09.001.

Érkezett: 2020. június 05.

Közlésre elfogadva: 2020. július 08. 